\title{
Number of Microorganisms in the Soil Cultivated with Legume-Grass Mixtures Supplied with Phytohormones and Nitrogen
}

\author{
Jacek SOSNOWSKI ${ }^{1}$, Kazimierz JANKOWSKI ${ }^{1}$, Roxana VIDICAN ${ }^{2 *}$, Beata \\ WIŚNIEWSKA-KADŻAJAN ${ }^{1}$, Elżbieta MALINOWSKA ${ }^{1}$, Anna KACZOREK ${ }^{1}$ \\ ${ }^{1}$ University of Natural Sciences and Humanities in Siedlce, Institute of Agronomy, 08-110 Siedlce, Poland; laki@uph.edu.pl \\ ${ }^{2}$ University of Agricultural Sciences and Veterinary Medicine Cluj-Napoca, \\ Romania; roxana.vidican@usamvcluj.ro (*correspondingauthor)
}

\begin{abstract}
The study concerned the number of microorganisms colonizing the humus layer and under plough soil from the cultivation of perennial ryegrass mixtures with red clover, which were fed by biostimulant based on the phytohormones and different doses of nitrogen. Nitrogen was applied at four levels-control (no nitrogen), 50, 100 and $150 \mathrm{~kg} \mathrm{~N} \cdot \mathrm{ha}^{-1}$, biostimulant in two combinations - with and without preparation. Soil material to assess the size of individual groups of microorganisms was collected from each experimental plot in autumn 2010 from the humus $(0-20 \mathrm{~cm})$ and under plough layers $(20-40 \mathrm{~cm})$. The analysis of soil samples for a total number of bacteria, actinomycetes and fungi was conducted at the Department of Agricultural Microbiology IUNG-PIB in Pulawy. Results of studies have shown that more colonies of bacteria, actinomycetes and fungi were colonized the humus horizon. Biostimulant application in this cultivation led to a decrease of the total number of colonies of the all soil microorganisms groups but improved the ratio of bacteria to fungi. Increasing doses of mineral nitrogen by the limiting of the bacteria number and intensive development of soil fungi, helped to narrow the $\mathrm{B} / \mathrm{F}$ ratio.
\end{abstract}

Keywords: bacteria, fungi, nitrogen, phytohormones, soil

\section{Introduction}

The conventional system of crop production was conducted in order to maximize yield through the intensive fertilization and plant protection treatment that has a major influence on soil characteristics. These practices caused the deterioration of biological and physico-chemical properties of the soil. (Martyniuk et al., 2001). Soil microorganisms affect not only the health of crops, but also the availability of nutrients for them, especially those that are released in the soil as a results of biological degradation and transformation of both fresh and stable soil organic matter (Nannipieri et al., 2000; Polyanskaya and Zvyaginstsev, 2005; Sveshnikova et al., 2001; Zvyaginstsev, 2011). The intensity of microbial transformation of the organic nitrogen and phosphorus compounds is very important in diversified fertilization conditions. Therefore, the soil fertility in macro-and micronutrients, and therefore its productivity are associated with the stable influx into the soil organic matter from plant residues, by the use of proper crop rotation with legumes or mixtures of grasses (Jodełka et al., 2011; Sveshnikova et al., 2001). Apart from microbial transformation of organic and inorganic nitrogen compounds, an important source of this element in soil may also be the microorganisms, that assimilate atmospheric nitrogen for example: free-living nitrogen fixing bacteria of the Azotobacter genus, especially nodules bacteria - Rhizobium and Bradyrbizobium - binds N2 in symbiosis with the roots of legumes (Ivanova et al., 2013; Martyniuk et al., 2001; Zvyaginstsev, 2011). In phosphorus transformation in the soil, both bacteria and fungi play an important role. Among the organisms mentioned above, a specific group stated mycorrhizal fungi. They create symbiotic systems with the roots of crop plants enabling them to take not only the available forms of phosphorus, but also other components such as micronutrient, increasing the absorptive surface of roots and producing appropriate enzymes (phosphatases) (Alabouvette, 2000). Mycorrhizal fungi also play an important role in creating a lumpy soil structure (Crecchio et al., 2007; Polyanskaya et al., 2012). 
In addition, soil microorganisms contribute to the distribution and detoxification of various soil pollutants (xenobiotics) (Burd et al., 1998; Gajda et al., 2010). They also put restraint to the development of pests and plant pathogens. This microbial activity is mostly connected with the occurrence of competition in the soil for food, among its inhabitants but also with the phenomena of antagonism and hyper parasitism. A few examples for these relationships are the inhibition by some soil bacteria, the development of phytopathogenic fungi, which produce different types of antibiotic substances or enzymes, decomposed by the fungal hyphen. Conversely, some soil fungi have the capability of riding on the nematodes and insects (Alabouvette, 2000; Compant et al., 2005; Jodełka et al., 2011).

In recent years, there has been observed the increase of interest in searching for new preparations, which application can improve the productivity and health of crops, reducing the use of mineral fertilizers and pesticides. Examples for this could be the substances derived from marine algae, which are considered as the most important group of living organisms that can be used on a large-scale in crop production. Literature data (Lipa and Pruszyński, 2010; Zodape, 2001) based on studies about algae extracts, indicate their positive impact on crops. The plants treated with extracts, are characterized by an increased yield, resulting mainly from increased plant unprofitable to adverse environmental factors (drought, frost), greater resistance to pests and pathogens and intensive nutrient uptake from the soil. Among the clusters of algae biostimulation effects on plants were observed. Green algae species are the most frequently mentioned: Cladophora dalmatica, Enteromorpha intestinalis, Ulva lactuca. Also red algaes: Corralina mediterranea, Jania rubens and Pterocladia pinnata and brown algaes: Ascophyllum nodosum, Ecklonia maxima, Saragassum spp. (Bai et al., 2007) have been mentioned. Biostimulation effects of the algae extracts are correlated with a large presence of plant hormones, mainly cytokines. Individual algae species differ in cytokinins content and in its proportions in relation to the other plant hormones. Therefore, the effect of algae extracts is not uniform (Reitz and Trumble, 1996; Verkleij, 1992). In addition, algae are considered as a rich source of micro- and macronutrients, which are necessary for plant growth. The action of algae extracts is strongly dependent on the concentration, application methods even as the species and varieties of the crop (Sultana at al., 2005).

The aim of this study was to determine the number of bacteria, actinomycetes and fungi located in the humus and under plough layer from the cultivation area of perennial ryegrass in combination with red clover supplied with phytohormones and different nitrogen dose.

\section{Materials and methods}

Soil material subjected to microbiological analysis came from a field experiment from the cultivation of perennial ryegrass $75 \%$, 'Diamond' in a mixture with red clover $25 \% \mathrm{cv}$. 'Parade'. It was established in the third decade of April 2009, by a randomized block design with three replications, in the experimental field of the Siedlce, University of Natural Sciences and Humanities. Experimental plot area was $6 \mathrm{~m}^{2}$. In the year of sowing only infestation cuts was carried out. The full period of this experiment was in the years 2010-2011. The soil on which the experiment was realized was classified in the medium soils category as anthropogenic soil. Before the experiment was established, the soil was characterized by a neutral reaction $(\mathrm{pH}$ in $\mathrm{KCl}=7.2)$, high abundance in humus $(3.78 \%)$, available phosphorus $\left(\mathrm{P}_{2} \mathrm{O}_{5}-600\right.$ $\left.\mathrm{mg} \cdot \mathrm{kg}^{-1}\right)$ and magnesium $\left(\mathrm{Mg}-74 \mathrm{mg} \cdot \mathrm{kg}^{-1}\right)$, average content of total nitrogen $\left(\mathrm{N}-1.6 \mathrm{~g} \cdot \mathrm{kg}^{-1}\right)$ and available potassium $\left(\mathrm{K}_{2} 0-16 \mathrm{mg} \cdot \mathrm{kg}^{-1}\right)$.

The experimental factors were as follow: nitrogen dose: A1-control (no nitrogen), A2-50, A3-100; A4$150 \mathrm{~kg} \cdot \mathrm{ha}^{-1}$ (nitrogen fertilizer applied in three doses in the form of $34 \%$ ammonium nitrate), biostimulant: B1 - control object (without biostimulant), B2 - biostimulant.

Growth regulator was used at a dose of $2 \mathrm{dm}^{3} \cdot \mathrm{ha}$ ${ }^{1}$, diluted in $350 \mathrm{dm}^{3}$ of water. This growth regulator contain natural plant hormones such as auxin (11 $\left.\mathrm{mg} \cdot \mathrm{dm}^{-3}\right)$ and cytokinins $\left(0.03 \mathrm{mg} \cdot \mathrm{dm}^{-3}\right)$ which was prepared from brown algae Ecklonia maxima $-32.2 \%$.

The preparation was used for all the regrowth in the form of spray.

Along the experimental years, on all plots potassium (60\% potassium salt) was used, which like nitrogen fertilization, were used on the regrowth in quantities of $160 \mathrm{~kg} \mathrm{~K} \mathrm{O} \cdot \mathrm{ha}^{-1}$ per year. Phosphorus (46\% superphosphate) at $40 \mathrm{~kg} \mathrm{P}_{2} \mathrm{O}_{5} \cdot \mathrm{ha}^{-1}$ per year was applied once in the spring.

The soil samples were collected from each plot in October 2011 from two levels: C1 - humus layer (0$20 \mathrm{~cm}), \mathrm{C} 2$ - under plough layer $(20-40 \mathrm{~cm})$. The analysis tests on the overall number of bacteria, actinomycetes and fungi was conducted at the Department of Agricultural Microbiology IUNGPIB in Pulawy.

The following methods and individual microbiological units were used:

-The total number of bacteria and actinomycetes $\left(10^{7} \mathrm{cfu} \cdot \mathrm{g}^{-1} \mathrm{DM}\right.$ of soil) was determined by Wallace and Lockheed (1950).

-The total number of fungi $\left(10^{7} \mathrm{cfu} \cdot \mathrm{g}^{-1} \mathrm{DM}\right.$ of soil) was determined by Martin (1950) method.

The obtained results were evaluated statistically using the analysis of variance. The mean differentiation was verified by Tukey's test, at significance level $\mathrm{p} \leq 0.05$. 
500

The climate conditions of the research area are typical for the IX - eastern agro-climatic district of Poland. The annual average temperature varies within 6.7-6.9 ${ }^{\circ} \mathrm{C}$. In summer, the average daily temperature reaches $15{ }^{\circ} \mathrm{C}$. Annual precipitation levels reach $550-650 \mathrm{~mm}$, while they are not frequent, but heavy. The vegetation period begins on the first decade of April and ends in the third decade of October therefore, it lasts from 200 to 220 days. Meteorological data from the years of research were obtained from the Hydrological and Meteorological Station in Siedlce. However, in order to determine the temporal and spatial variability of meteorological elements and their effects on vegetation, it was calculated the hydrometrical ratio of Sielianinow. Data presented in Tab. 1 indicate that the most favorable distribution and amount of rainfall, with optimum air temperatures within the growing period of plants was the year 2010. In that year, there were no months with strong drought in contrast to the year 2011 .

\section{Results and discussion}

In some studies (Doran and Parkin, 1994; Marinari et al., 2006; Myśków and Zięba, 1997) was underlined the fact that some of the parameters, on comprising the microbiological properties of soils, can be modified by both the direct impact of some agricultural treatment on microbial activity as well as indirectly by changing the physical and chemical properties of the soil.

The assessment of the microorganisms number (Tabs. 2, 4) indicates that, the application of biopreparation in cultivation of perennial ryegrass with red clover, regardless of the nitrogen dose and sampling levels of soil resulted in more than $48 \%$ reduction in the number of soil bacteria, $16 \%$ of actinomycetes and over $26 \%$ of fungi. Noteworthy is the fact that the use of biostimulant without nitrogen fertilization (Tab. 2) has resulted in a significant increase in the number of bacterial colonies from 41.71 to $118.110^{7} \mathrm{cfu} \cdot \mathrm{g}^{1}$ D.M.soil.

Wyszkowska et al. (2000) showed that different groups of organisms react differently on the application of plant hormone compounds. Only the application of gibberellic acid caused an increase in the number of bacterial colonies compared to control. Indolilobutyric acid, $\alpha$-naphtaleneacetic, triacontanol and benzyladenine significantly limited the development of these organisms. Actinomycetes preferably reacted to indolilobutyric acid, and fungi on benzyladenine treatment. It should have to be emphasized that hormones, used in the cited studies at least degree, limiting the number of fungi, which was not confirmed in our study.

Jodełka et al. (2011), Wyszkowska et al. (2000) in

Tab. 1. Value of hydrometrical index of Sielianinow $(\mathrm{K})$ in individual months of vegetation

\begin{tabular}{cccccccc}
\hline \multirow{2}{*}{ Year } & \multicolumn{7}{c}{ Month } \\
\cline { 2 - 7 } & IV & V & VI & VII & VIII & IX & X \\
\hline 2010 & 0,40 & 2.21 & 1.19 & 1.18 & 1.79 & 2.81 & 0.53 \\
2011 & 1.10 & 0.89 & 0.72 & 2.19 & 0.84 & 0.78 & 0.94 \\
\hline
\end{tabular}

Tab. 2. The total number of bacteria $\left(10^{7} \mathrm{cfu} \cdot \mathrm{g}^{-1}\right.$ D.M. soil $)$, depending on the nitrogen dose, biostimulant and soil level

\begin{tabular}{|c|c|c|c|c|}
\hline \multicolumn{2}{|c|}{ Factors } & \multicolumn{2}{|c|}{ Level (C) } & \multirow{2}{*}{$\bar{x}$} \\
\hline Nitrogen dose (A) & Biostimulant (B) & $\mathrm{C} 1$ & $\mathrm{C} 2$ & \\
\hline \multirow{3}{*}{ A 1} & B1 & 45.29 & 38.13 & 41.71 \\
\hline & B2 & 129.7 & 106.5 & 118.1 \\
\hline & & 87.40 & 72.35 & 80.05 \\
\hline \multirow{3}{*}{$\mathrm{A} 2$} & B1 & 258.0 & 172.4 & 215.2 \\
\hline & B2 & 40.53 & 32.90 & 36.72 \\
\hline & & 149.2 & 102.6 & 125.8 \\
\hline \multirow{3}{*}{ A3 } & B1 & 213.4 & 163.8 & 188.6 \\
\hline & B2 & 53.97 & 41.09 & 47.5 \\
\hline & & 133.6 & 102.4 & 118.0 \\
\hline \multirow{3}{*}{ A 4} & B1 & 72.89 & 56.66 & 64.77 \\
\hline & B2 & 67.79 & 55.32 & 61.56 \\
\hline & & 70.35 & 55.99 & 63.16 \\
\hline \multirow{3}{*}{ B } & B1 & 147.5 & 107.7 & 127.6 \\
\hline & B2 & 73.00 & 58.98 & 65.98 \\
\hline & & 110.27 & 83.37 & - \\
\hline & $-29,52 . ; B-53$ & $\mathrm{AxB}-4$ & $\mathrm{C}-32$ & \\
\hline
\end{tabular}

Nitrogen: A1-control (no nitrogen), A2 - 50, A3 - 100, A4 - $150 \mathrm{~kg} \cdot \mathrm{ha}^{-1}$, biostimulant: B1 - control object (without biostimulant), B2 - biostimulant, the level of sampling: $\mathrm{C} 1$ - a layer of humus $(0-20 \mathrm{~cm}), \mathrm{C} 2$ - under phlought layer $(20-40 \mathrm{~cm})$ 
their studies highlight the impact of mineral fertilizers, especially nitrogen on soil microbial life, which is reflected in its numbers. The highest number of bacteria (approximately $122 \cdot 10^{7} \mathrm{cfu} \cdot \mathrm{g}^{-1}$ D.M. soil) occurred in the samples from plots fertilized with 50 and $100 \mathrm{~kg} \mathrm{~N} \cdot \mathrm{ha}^{-1}$. Increasing doses of nitrogen to $150 \mathrm{~N} \cdot \mathrm{ha}^{-1}$ reduced the growth of these organisms, and caused intensive growth of fungi colonies. This is confirmed in other publications (Rekosz-Burlaga and Russel, 1999) and must be explained by over fertilization soil with the mineral nitrogen, which leads to an excessive concentration of nitrosamines in soil solution, which are toxic for bacteria.
The most strongly developed actinomycetes have developed in soils, which were supplied with 150 , and $50 \mathrm{~kg} \mathrm{~N} \cdot \mathrm{ha}^{-1}$ and their number varied from 40.95 to $45.97-10^{7} \mathrm{cfu} \cdot \mathrm{g}^{-1}$ D.M. soil (Tab. 3) and exceeded $20 \%$. This number was higher than the total number of colonies observed in the soil material came from the control objects and fertilization with $100 \mathrm{~kg}$ $\mathrm{N} \cdot \mathrm{ha}^{-1}$.

Microbiological quantitative analysis for the soil level samples indicates that significantly more colonies of bacteria, actinomycetes and fungi were colonized the humus horizon. However nitrogen and biostimulant were applied, there were average $24 \%$ more bacteria, $26 \%$ actinomycetes, and $23 \%$ fungi

Tab. 3. The total number of actinomycetes $\left(10^{7} \mathrm{cfu} \cdot \mathrm{g}^{-1}\right.$ D.M. soil), depending on the nitrogen dose, biostimulant and soil level

\begin{tabular}{|c|c|c|c|c|}
\hline \multicolumn{2}{|c|}{ Factors } & \multicolumn{2}{|c|}{ Level (C) } & \multirow{2}{*}{$\bar{x}$} \\
\hline Nitrogen dose (A) & Biostimulant (B) & $\mathrm{C} 1$ & $\mathrm{C} 2$ & \\
\hline \multirow{3}{*}{ A1 } & B1 & 34.64 & 25.49 & 30.07 \\
\hline & B2 & 40.47 & 29.18 & 34.83 \\
\hline & & 37.56 & 23,17 & 32.44 \\
\hline \multirow{3}{*}{ A2 } & B1 & 66.68 & 42.63 & 54.65 \\
\hline & B2 & 42.31 & 32.22 & 37.27 \\
\hline & & 54.50 & 37.43 & 45.97 \\
\hline \multirow{3}{*}{ A3 } & B1 & 32.75 & 24.78 & 28.77 \\
\hline & B2 & 43.33 & 34.14 & 38.74 \\
\hline & & 38.04 & 29.47 & 33.75 \\
\hline \multirow{3}{*}{ A4 } & B1 & 58.63 & 47.83 & 53.24 \\
\hline & B2 & 33.73 & 23.60 & 28.68 \\
\hline & & 46.19 & 35.72 & 40.95 \\
\hline \multirow{3}{*}{ B } & B1 & 48.17 & 35.18 & 41.69 \\
\hline & B2 & 39.96 & 29.79 & 34.88 \\
\hline & & 44.06 & 32.48 & - \\
\hline
\end{tabular}

Nitrogen: A1-control (no nitrogen), A2 - 50, A3 - A4 100 - $150 \mathrm{~kg} \cdot \mathrm{ha}^{-1}$, biostimulant: B1 - control object (without biostimulant), B2 - biostimulant, the level of downloads: C1 - a layer of compost $(0-20 \mathrm{~cm}), \mathrm{C} 2$ - under plough layer $(20-40 \mathrm{~cm})$

Tab. 4. The total number of fungi $\left(10^{7} \mathrm{cfu} \cdot \mathrm{g}^{-1}\right.$ D.M. soil), depending on the nitrogen dose, biostimulant and soil level

\begin{tabular}{|c|c|c|c|c|}
\hline \multicolumn{2}{|c|}{ Factors } & \multicolumn{2}{|c|}{ Level (C) } & \multirow{2}{*}{$\bar{x}$} \\
\hline Nitrogen dose (A) & Biostimulant (B) & $\mathrm{C} 1$ & $\mathrm{C} 2$ & \\
\hline \multirow{2}{*}{ A1 } & B1 & 23.45 & 13.41 & 18.43 \\
\hline & B2 & 9.510 & 5.960 & 7.740 \\
\hline \multicolumn{2}{|c|}{ A1 } & 16.49 & 9,69 & 13.08 \\
\hline \multirow{3}{*}{ A2 } & B1 & 41.21 & 30.40 & 35.81 \\
\hline & B2 & 25.95 & 21.48 & 23.71 \\
\hline & & 33.58 & 25.94 & 29.76 \\
\hline \multirow{3}{*}{ A3 } & B1 & 33.80 & 26.08 & 29.94 \\
\hline & B2 & 28.54 & 24.10 & 26.33 \\
\hline & & 31.18 & 25.09 & 28.13 \\
\hline \multirow{3}{*}{ A4 } & B1 & 50.18 & 41.39 & 45.79 \\
\hline & B2 & 42.45 & 32.19 & 37.32 \\
\hline & & 46.31 & 36.79 & 41.56 \\
\hline \multirow{3}{*}{ B } & B1 & 37.17 & 27.83 & 32.50 \\
\hline & B2 & 26.62 & 20.93 & 23.77 \\
\hline & & 31.89 & 24.38 & - \\
\hline
\end{tabular}

Nitrogen: A1-control (no nitrogen), A2 - 50, A3 - A4 100 - $150 \mathrm{~kg} \cdot \mathrm{ha}^{-1}$, biostimulant: B1 - control object (without biostimulant), B2 - biostimulant, the level of downloads: C1 - a layer of compost $(0-20 \mathrm{~cm}), \mathrm{C} 2$ - under plough layer $(20-40 \mathrm{~cm})$ 
Tab. 5. The ratio of bacteria to fungi, depending on the nitrogen dose applied, biostimulant and soil level

\begin{tabular}{|c|c|c|c|c|}
\hline \multicolumn{2}{|c|}{ Factors } & \multicolumn{2}{|c|}{ Level (C) } & \multirow{2}{*}{$\bar{x}$} \\
\hline Nitrogen dose (A) & Biostimulant (B) & $\mathrm{C} 1$ & $\mathrm{C} 2$ & \\
\hline \multirow{3}{*}{ A1 } & B1 & 1.93 & 2.84 & 2.39 \\
\hline & B2 & 13.6 & 17.8 & 15.7 \\
\hline & & 7.78 & 10.36 & 9.07 \\
\hline \multirow{3}{*}{ A2 } & B1 & 6.26 & 3.04 & 4.65 \\
\hline & B2 & 1.56 & 1.53 & 1.55 \\
\hline & & 3.91 & 3.80 & 3.86 \\
\hline \multirow{3}{*}{ A3 } & B1 & 6.31 & 6.28 & 6.30 \\
\hline & B2 & 1.89 & 1.70 & 1,80 \\
\hline & & 4.10 & 3.99 & 4.05 \\
\hline \multirow{3}{*}{ A4 } & B1 & 1.45 & 1.72 & 1.59 \\
\hline & B2 & 1.60 & 1.74 & 1.67 \\
\hline & & 1.53 & 1.73 & 1.63 \\
\hline \multirow{4}{*}{ B } & B1 & 3.99 & 3.47 & 3.73 \\
\hline & B2 & 4.67 & 5.71 & 5.19 \\
\hline & & 4.33 & 4.59 & - \\
\hline &, 05 dla: $\mathrm{A}-3,33 ; \mathrm{B}$ & $\mathrm{AxB}-$ & -r.n.; & \\
\hline
\end{tabular}

Nitrogen: A1-control (no nitrogen), A2 - 50, A3 - A4 100 - $150 \mathrm{~kg} \cdot \mathrm{ha}^{-1}$, biostimulant: B1 - control object (without biostimulant), B2 - biostimulant, the level of downloads: $\mathrm{C} 1$ - a layer of compost $(0-20 \mathrm{~cm}), \mathrm{C} 2$ - under plough layer $(20-40 \mathrm{~cm})$

(Tab. 4) in this layer. According to a research, concerning the evaluation of biological properties of soil from cultivation of amaranth (Skwaryło-Bednarz, 2008) the difference between the quantity of these microorganisms can reach $50 \%$. It is worth noting that, according to cited research, the number of microorganisms in different layers also depend on crop variety and the season of the year. In autumn samples, aside from the other experimental factors, the number of microflora was much higher in the humus layer and in the subsoil layer than in the spring samples. This increase it is attributable to the fact that more precipitation occurred in this period.

Similar results were obtained by analyzing the biological properties of the soil in the cultivation of winter wheat (Frąc et al., 2011). Independently of the production system (conventional or organic), the number of bacteria and fungi were higher in $0-10 \mathrm{~cm}$ of soil layer. The increase was caused by the utilization of the organic matter introduced into soil by microorganisms with after-harvest residue due to the rotation system applied and due to the secretion of root crops. In addition, the reduction of microbial number in the lower layer of the soil profile was the consequence of the access limitation by microorganisms to use carbon substrates.

According to production, an important characteristic of microorganisms is to create a symbiotic association with plants (Martyniuk, 2009; Martyniuk, 2011; Sveshnikova et al., 2001). The most studied example of symbiosis is the coexistence of papillary bacteria (rhizobia) with legume plants. The exchange of the nutrients between these partners takes place in root nodules in which rhizobia transmits the nitrogen taken from the atmosphere to plants. In return, they collect carbohydrates as a source of energy necessary to carry out the process of bacteria to reduce atmospheric nitrogen. This process is beneficial from both ecological and agricultural point of view, because it contributes to the reduction of nitrogen fertilization. Another type of symbiosis is mycorrhiza symbiosis, which exists between fungi species from the soil and plant roots. In this case, the mycorrhiza fungus facilitates for partner the collection of water and mineral salts and also protects plant roots from pathogenic fungi (Martyniuk, 2011). It is well known the fact that soil microorganisms through transformation processes of organic matter, are largely responsible for the availability of nutrients for plants. Therefore, the large number, activity and diversity of microorganisms are influential factors for a good quality and productivity of the soil (Marinari et al., 2006; Masto et al., 2006; Polyanskaya and Zvyaginstsev, 2005). A good indicator for estimation of the soil quality fertility is the ratio of the number of bacteria to fungi - B/F (Buryukhaev et al., 1985; Gajda et al., 2010; Myśków and Zięba, 1997). Higher values of this parameter inform about the relatively weak development of fungi, but less proved about their strong participation.

Due to the phytopathogenic and toxic characteristics of fungi, their increased development is negative in terms of fertility and productivity of the soil (Bis, 2006; Buryukhaev et al., 1985; Gajda et al., 2010; Wielgosz and Szember, 2006). It is worth noting, that the most profitable value of $B / F$ (Tab. 5), aside from the level of sample collection, reach an average of 18,4 . This average resulted from the object without nitrogen -A1, powered only by phytohormones. Higher doses of nitrogen decreased the index value limiting the effect of biostimulant. It should be noted, that the lowest $\mathrm{B} / \mathrm{F}$ at 1.63 was obtained for samples taken from objects fertilized with nitrogen in an amount of $150 \mathrm{~kg}$ per ha.

Interaction between biostimulant and soil sample collection depth did not affect significantly the variation in question characteristics. In addition, statistical analysis showed that aside from other 
experimental factors, soil sample levels did not significantly affect the evolution of the ratio of bacteria to fungi.

\section{Conclusions}

Biostimulant application based on the phytohormons in the cultivation of perennial ryegrass in a mixture with red clover, caused a decrease in the total number of colonies of all groups of soil microorganisms, but increased the ratio of the number of bacteria to fungi.

Increasing the dose of mineral nitrogen to 150 $\mathrm{kg} \cdot \mathrm{ha}^{-1}$ contributed to more intensive growth of soil fungi and reduced the number of bacterial colonies, which indeed resulted in the deterioration of soil biological quality expressed as the number ratio of bacteria to fungi.

\section{Acknowledgements}

The research carried out under the project of the Ministry of Science and Higher Education for the development of young scientists. Topic title: Effect of some biological preparations on soil fertility and productivity of plants alternating grassland; project number $20 / \mathrm{MN} / 11$.

\section{References}

Alabouvette C (2000). Biological control of plant disease, p. 257 264. In: Balazs E, Galante E, Lynch JM, Schepers JS, Werner D, Toutant JP, Werry PA (eds). Biological Resource Management Springer, Germany.

Bai NR, Banu NRL, Prakash JW, Goldi SJ (2007). Effects of Asparagopsis taxiformis extract on the growth and yield of Phaseolus aureus. Journal of Basic and Applied Biology 1(1): 611.

Bis $H$ (2006). Ability to produce mycotoxins by fungi isolated from soils in Cracow and the surroundings. Zesz. Nauk. Uniwersytetu Przyrodniczego we Wrocławiu. Rol. LXXXIX 546:43-50.

Burd GI, Dixon DG, Glick BR (1998). A plant growthpromoting bacterium that decreases nickel toxicity in seedlings. Appl Environ Microbiol 64:3663-3668.

Buryukhaev SP, Namsaraev BB, Korsunov VB, Gonchikov GG (1985). The abudance of microorganisms and the dynamics of decomposition rates in low moor bogs of the Baikal region. Eur Soil Sci 36(1):76-84.

Compant S, Duffy B, Nowak J, Clement Ch, Barka A (2005). Use of plant growth-promoting bacteria for biocontrol of plant diseases: principles, mechanisms of action, and future prospects. Appl Environ Microbiol 71(9):4951-4959.

Crecchio C, Curci M, Pellegrino A, Ricciuti P, Tursi N, Ruggiero $P$ (2007). Soil microbial dynamics and genetic diversity in soil under monoculture wheat grown in different long-term management systems. Soil Biol Biochem 39:1391-1400.
Doran JW, Parkin TB (1994). Defining and assessing soil quality, p. 3-21. In: Doran JW, Coleman DC, Bezdicek DE, Stewart BA (eds). Defining soil quality for a sustainable environment. Soil Science Society of America, Madison.

Frąc M, Lipiec J, Rutkowska A, Oszust K, Półtorak M (2011). Microbiological properties of soil under winter wheat in the ecological and conventional cropping systems. Acta Agrophysica 18(2):245-254.

Gajda AM, Przewłoka B, Gawryjołek K (2010). Determination of the effect of used tillage system on changes of soil environment measured with parameters of soil microbiological activity. Nauka Przyroda Technol 4(6):1-11.

Ivanova TI, Kuz'mina NP, Savvinov DD (2013). Microbial cenoses of alas soils on the Lena-Agma interfluve in Central Yakutia. Eur Soil Sci 46(4):417-430.

Jodełka J, Jankowski K, Sosnowski J (2011). Effect of nitrogen fertilization on microbial properties of meadow soil. Rom Agric Res 28:181-186.

Lipa J, Pruszyński S (2010). Scale of use of biological methods in plant protection in poland and in the world. Prog Pl Prot/Post Ochr Roślin 50:1033-1043.

Marinari S, Mancinelli R, Campiglia E, Grego S (2006). Chemical and biological indicators of soil quality in organic and conventional farming systems in Italy. Ecol Indic 6:701-711.

Martin JP (1950). Use of acid, rose bengal and streptomycin in the plate method for estimating soil fungi. Soil Sci 69:215-232.

Martyniuk S (2009). Production of microbial preparations: symbiotic bacteria of legumes as an example. J Res Appl Agrict Eng 55:20-23.

Martyniuk S (2011). Effective and ineffective microbial preparations used in plant protection and production and methods of their evaluation. Post Mikrobiol 50(4):321-328.

Martyniuk S, Gajda A, Kuś J (2001). Microbiological and biochemical properties of soils under cereals grown in the ecological, conventional and integrated system. Acta Agrophysica 52:185-192.

Masto RE, Chhonkar PK, Singh D, Patra AK (2006). Changes in soil biological and biochemical characteristics in long-term field trial on a sub-tropical inceptisol. Soil Biol Biochem 38:15771584.

Myśków W, Zięba S (1997). The biological activity of the soil in terms of soil fertility. Microbial participation in the formation of soil properties. Biul Inf Inst Uprawy Nawoż Glebozn 15:24-26.

Nannipieri P, Falchini L, Landi L, Pietramellara G (2000). Management of soil microbiota In: Balazs E., Galante E., Lynch J.M., Schepers J.S., Werner D., Toutant J.P., Werry P.A. (eds) Biological Resource Management, Springer, Germany 237-255.

Polyanskaya LM, Zvyaginstsev DG (2005). The content and composition of microbial biomass as an index of the Ecological status of soil. Eur Soil Sci 38(6):625-633.

Polyanskaya LM, Sukhanova NI, Chakmazyan KV, Zvyaginstsev DG (2012). Changes in the structure of soil microbial biomass under fallow. Eur Soil Sci 45(7):710-716. 
504

Reitz SR, Trumble JT (1996). Effects of cytokinin-conteining seaweed extract on Pheasolus lunatus L. influence of nutrient availability and apex removal. Bot Mar 39(1):33-38.

Rekosz-Burlaga H, Russel S (1999). The effect of irrigation on the occurrence of different microorganisms groups in the soil of apple-trees orchard after replanted. Zesz Prob Post Nauk Rol 465:527-533.

Skwaryło-Bednarz B (2008). Ocena właściwości biologicznych gleby pod uprawą szarłatu (Amaranthus cruentus L.). Acta Agrophysica 12(2):527-534.

Sultana V, Ehteshamul-Haque S, Ara J, Athar M (2005) Comparative efficacy of brown, green and red seaweeds in the control of root infecting fungi and okra. Int J Environ Sci Tech 2(2):129-132.

Sveshnikova AA, Polyanskaya LM, Lukin SM (2001). Microbial complex of soils under various land use types in the Vladimir Olbast. Eur Soil Sci 34(4):409-415.

Verkleij FN (1992) Seaweed extracts in agriculture and horticulture: a review. Biol Agric Hortic 8:309-324.
Wallace RH, Lockhead AG (1950). Qualitative studies of soil microorganisms. Aminoacid requirements of rhizosphere bacteria. Can J Res 28:1-6.

Wielgosz E, Szember A (2006). The effect of selected plants on the number and activity of soil microorganisms. Ann. UMCS, Sect. E, 61:107-119.

Wyszkowska J, Kucharski J, Nowak G (2000). Role of phytohormones and their precursors in modifying of enzymatic activity of soil and number of microorganisms. Natur Sci 7:17-30.

Zodape ST (2001). Seaweeds as a biofertilizer. J Sci Ind Res 60(5):378-382.

Zvyaginstsev DG (2011). Regulation of soil microbial communities and their impact on plant growth. Eur Soil Sci 44(11):1276-1277. 